\title{
Relation of growth to ingestion for larvae of Atlantic herring Clupea harengus and other fish*
}

\author{
David M. Checkley, Jr. \\ Marine Laboratory, Aberdeen, Scotland \\ and \\ The University of Texas at Austin**, Marine Science Institute, Port Aransas, Texas 78373, USA
}

\begin{abstract}
Larvae of Atlantic herring Clupea harengus were reared on wild plankton and Artemia salina nauplii in the laboratory at 7 to $9^{\circ} \mathrm{C}$ for $95 \mathrm{~d}$. Between ages of 20 and $38 \mathrm{~d}$, larvae were fed only Artemia nauplii and the specific rates of ingestion and growth were measured and compared. Relations of rate and efficiency of growth to ingestion were similar in terms of carbon and nitrogen. Growth was linearly related to ingestion $\left(r^{2}=0.89, n=9\right)$. Starved larvae lost mass at a specific rate of $0.03 \mathrm{~d}^{-1}$ $\left(3 \% \mathrm{~d}^{-1}\right)$ until death at $14 \mathrm{~d}$. A specific ingestion rate of $0.04 \mathrm{~d}^{-1}$ was required to balance defecation and metabolism. Gross growth efficiency (growth rate/ingestion rate) rose from -1.2 at a low ingestion rate $\left(0.015 \mathrm{~d}^{-1}\right)$ to 0.4 at the greatest observed ingestion rate $\left(0.11 \mathrm{~d}^{-1}\right)$. Condition factor (dry weight length $\left.{ }^{-3}\right)$ was significantly related to both ingestion rate and length $\left(r^{2}=0.69, n=20\right)$. These results, combined with those for other fish larvae, indicate an asymptotic relation between rates of growth and ingestion such that gross growth efficiency is maximal $(0.4)$ at intermediate ingestion rate. Fish larvae surviving in the sea appear to maximize their ingestion rate and thus grow rapidly but with a reduced efficiency.
\end{abstract}

\section{INTRODUCTION}

The objective of the present study was to investigate food-limited growth of Atlantic herring Clupea harengus larvae. I posed 2 questions. First, do herring larvae maximize the rate at which they ingest food or the efficiency with which they produce tissue from ingested food? Second, do the chemical composition, in terms of dry weight, carbon, and nitrogen, and the condition factor vary in relation to ingestion, so that they might be used to infer about the nutrition of wildcaught fish larvae? Similar investigations have been made with sated and starved fish larvae, and with larvae maintained in various concentrations of prey. However, few observations of chemical composition, condition factor, and rates of ingestion and growth have been made of fish larvae ingesting food over a range of known, growth-limiting rates between starvation and satiation.

Growth is related to ingestion by a monotonicallyincreasing function, such as a linear (Jones, 1976),

\footnotetext{
- The University of Texas Marine Science Institute Contribution No. 625

* Present address
}

rectilinear (Condrey, 1982), or logarithmic (Edwards et al., 1969) relation. Gross growth efficiency, $K_{1}$, is defined here as the ratio of the rates of growth and ingestion (Ivlev, 1961). $K_{1}$ is the fraction of ingested food incorporated into tissue and may be computed in terms of material (e.g. the weight of dry matter, carbon, or nitrogen) or energy. The relation of $\mathrm{K}_{1}$ to ingestion is peaked: $\mathrm{K}_{1}$ is zero when enough food is ingested only to satisfy metabolism, is maximal at an intermediate ingestion rate, and declines thereafter (Webb, 1978; Brett and Groves, 1979). The latter, descending portion of the $\mathrm{K}_{1}$-ingestion relation has most often been observed in laboratory studies of larval fish (Stepien, 1976; Houde and Schekter, 1981). It is conceivable, however, that in nature food availability is sub-optimal and hence that growth proceeds at a rate slower than maximal but with an optimal efficiency (Calow, 1977), thereby enabling the greatest production from a given food supply (Roughgarden, 1971).

Various physical and chemical characteristics vary predictably during starvation for fish larvae and hence have been suggested as potential indices of nutrition in nature (e.g. Ehrlich et al., 1976; Theilacker, 1978; Buckley, 1979, 1980; O'Connell, 1980). Chemical composition - including the relative weights of dry matter, 
carbon, and nitrogen - change during starvation for larval Atlantic herring (Ehrlich, 1974a). Similarly, the condition factor of larval Atlantic herring decreases during starvation (Hempel and Blaxter, 1963; Ehrlich et al., 1976). However, the relations of these potential indices to ingestion rate remains unstudied.

In the present study, larvae of Atlantic herring were reared in the laboratory for $95 \mathrm{~d}$. Rates of ingestion and growth were measured for fish between ages of 20 and $38 \mathrm{~d}$. A mixture of wild plankton and Artemia salina nauplii was offered to the stock population as food while fish used experimentally to investigate ingestion and growth were fed only Artemia nauplii. Relations of growth, gross growth efficiency, chemical composition, and condition factor to ingestion are discussed. Results are then compared with those for other species to derive a general relation between growth and ingestion for larval fish.

\section{MATERIALS AND METHODS}

Ripe Atlantic herring were obtained in Feb 1978 near Ballantrae Bank off the west coast of Scotland, their gonads removed, and gametes fertilized in the laboratory (Blaxter, 1968). Zygotes and resultant larvae were maintained in 981 black tubs at 7 to $9^{\circ} \mathrm{C}$ with overhead fluorescent illumination on a 12L:12D cycle. Water flowed from the rearing tubs to a 271 reservoir and was aerated and filtered coarsely before recycling to the rearing containers. Approximately one third of the system's seawater was replaced each week with seawater collected from Loch Ewe on the west coast of Scotland. Artemia nauplii younger than $2 \mathrm{~d}$ and wild plankton, collected twice weekly with a $60 \mu \mathrm{m}$ mesh net from Aberdeen Bay, were provided daily as food. Sediment, including feces and dead and moribund animals, was siphoned daily from the rearing containers. Fish were periodically removed from rearing containers, anesthetized with MS-222, standard length measured, placed on a tared and baked $\left(500^{\circ} \mathrm{C}, 1 \mathrm{~h}\right)$ glass fiber filter, dried $\left(60^{\circ} \mathrm{C}, 24 \mathrm{~h}\right)$, and weighed.

Experimental fish were removed from the stock population at age $20 \mathrm{~d}$, anesthetized with MS-222, their standard length measured, and transferred to 2.51 white polyethylene containers. Each of 12 containers received 7 measured fish. Few larvae died during transfer; these losses were replaced with healthy larvae of known length the following morning. Nine additional fish were anesthetized, measured, and dried as described earlier for initial determinations of dry weight, carbon, and nitrogen. Experimental fish were maintained under similar light and temperature conditions as the stock population.
Four treatments consisted of daily additions to each 2.51 container of either $0,25,50$, or $2501 \mathrm{~d}$ old Artemia nauplii. The first treatment, starvation, consisted of 3 containers with fish. The 3 treatments with food each consisted of 2 containers without and 3 containers with fish. Dead fish were removed daily, rinsed with distilled water, and placed on a tared filter to dry at $60^{\circ} \mathrm{C}$. Live fish were transferred by pipette to clean experimental containers every $4 \mathrm{~d}$ and the Artemia nauplii remaining in the old containers with and without fish were collected and counted. The food consumed by fish in each container was taken as the difference between the mean number of food items in containers lacking fish and the number remaining in containers with fish. Recovery of food items added to containers without fish varied between 94 and $98 \%$. After $18 \mathrm{~d}$ (age $38 \mathrm{~d}$ ), the experiment was ended by measuring and drying individually-anesthetized fish, as described above. Samples of one hundred 1 and $2 \mathrm{~d}$ old Artemia nauplii were dried on tared filters at $60^{\circ} \mathrm{C}$ for dry weight and elemental analyses.

Dried larvae $\left(60^{\circ} \mathrm{C}, 24 \mathrm{~h}\right)$ were weighed using a Perkin Elmer Model $2 \mathrm{ADZ}$ electrobalance $( \pm 1 \mu \mathrm{g})$. Carbon and nitrogen were measured using a Hewlett Packard Model 185 CHN analyzer. Symbols and calculations used to compute ingestion and growth rates and gross efficiency of growth are presented in Tables 1 and 2. Results are presented and discussed in terms of nitrogen, because nitrogen often limits the production of marine plankton (e.g. Thomas, 1970; Checkley, 1980) and is closely related to growth for fishes (Gerking, 1971). $\mathrm{W}_{\mathrm{O}}$, the average initial nitrogen content of fish in a container, was estimated from the initial lengths of experimental fish and the power curve relating bodily nitrogen to length for fish sacrificed at the beginning of the experiment. $\mathrm{W}_{\mathrm{j}}$ was either measured directly $(n=32)$ or estimated $(n=52)$ from a fish's dry weight and the regression of bodily nitrogen on dry

Table 1. Symbols used

\begin{tabular}{|c|c|c|}
\hline Symbol & Explanation & Unit \\
\hline $\mathrm{n}$ & Fish per container initially & fish \\
\hline$t_{j}$ & $\begin{array}{l}\text { Duration jth fish remained } \\
\text { alive in expt. }\end{array}$ & d \\
\hline$L_{j}$ & Standard length of jth fish & $\mathrm{mm}$ \\
\hline $\mathrm{w}_{\mathrm{O}}$ & Average initial bodily $\mathrm{N}$ & $\mu \mathrm{g} \mathrm{N}$ fish $^{-1}$ \\
\hline$w_{j}$ & Final bodily $\mathrm{N}$ of $\mathrm{jth}$ fish & $\mu \mathrm{g} \mathrm{N}$ fish $^{-1}$ \\
\hline w & Average bodily $\mathrm{N}$ of fish in expt. & $\mu \mathrm{g} \mathrm{N}$ fish $^{-1}$ \\
\hline $\mathrm{N}_{\mathrm{p}}$ & Prey consumed per container & prey \\
\hline $\mathrm{W}_{\mathrm{p}}$ & Nitrogen per prey & $\mu \mathrm{g} \mathrm{N}^{\mathrm{N}}$ prey $^{-1}$ \\
\hline I & Ingestion rate & $\mu \mathrm{g} \mathrm{N}$ fish $^{-1} \mathrm{~d}^{-1}$ \\
\hline $\mathrm{i}$ & Specific ingestion rate & $d^{-1}$ \\
\hline $\mathrm{G}$ & Growth rate & $\mu \mathrm{g} \mathrm{N}$ fish $^{-1} \mathrm{~d}^{-1}$ \\
\hline g & Specific growth rate & $\mathrm{d}^{-1}$ \\
\hline $\mathrm{K}_{1}$ & Gross growth efficiency & dimensionless \\
\hline
\end{tabular}


Table 2. Equations describing ingestion and growth

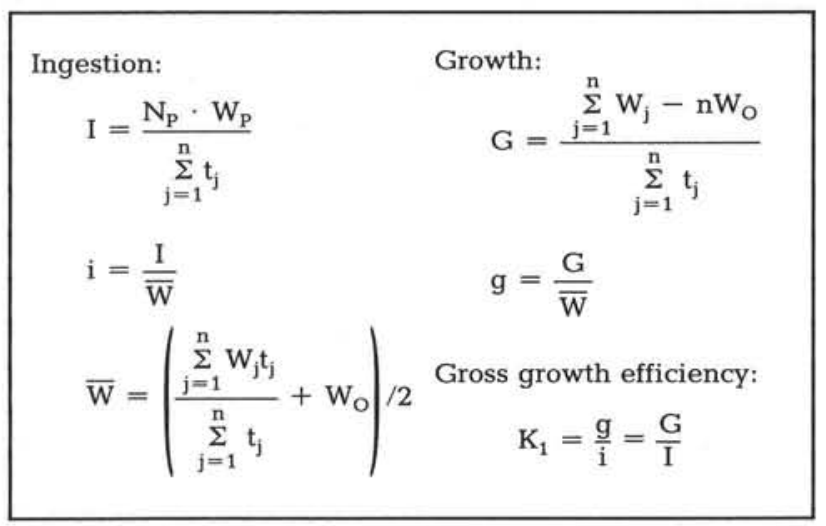

weight for experimental fish. Specific rates (mass mass $^{-1}$ time $^{-1}=$ time $^{-1}$ ) are used to enable comparisons between fish of different sizes (Morgan, 1981). Specific rates in units of $\%$ bodily nitrogen $d^{-1}$ may be computed by multiplying the rates reported here by 100 .

Condition factor was computed from fish length $(\mathrm{L}$, $\mathrm{mm})$ and dry weight $\left(\mathrm{W}_{\mathrm{D}}, \mathrm{mg}\right)$ (Hempel and Blaxter, 1963):

$$
\mathrm{CF}=\frac{\mathrm{W}_{\mathrm{D}}}{\mathrm{L}^{3}} \cdot 100
$$

for fish surviving at the experiment's end. The length of fish found dead during the experiment, including all starved fish, could not be measured accurately and hence a condition factor could not be computed.

\section{RESULTS}

Larvae in the stock culture grew in length $0.17 \mathrm{~mm} \mathrm{~d}^{-1}$ (Fig. 1) after hatching at approximately $10.5 \mathrm{~mm}$. Dry weight $\left(\mathrm{W}_{\mathrm{D}}, \mu \mathrm{g}\right)$ was closely related to larval length $(\mathrm{L}, \mathrm{mm})$ by the power function $\mathrm{W}_{\mathrm{D}}=$ $0.000664 L^{4.73}\left(r^{2}=0.97, n=101, F_{1,99}=3,375\right.$, $\mathrm{p} \ll 0.01$ ). Significant unplanned mortality of stock larvae occurred but was not measured.

Survivorship curves and initial bodily nitrogen of the experimental larvae are shown in Fig. 2. Larvae without food died after an average of $14 \mathrm{~d}$ and not more than $17 \mathrm{~d}$. The number of larvae surviving the first $9 \mathrm{~d}$ was positively related to the average size of larvae in a container at the beginning of the experiment (Tukey Corner test, $\mathrm{n}=12, \mathrm{p}<0.05$ ). Survival of larvae with food did not appear to be related to food supply: an average of 4 to 5 larvae in each container to which food was added survived the $18 \mathrm{~d}$ experiment.

Nitrogen content was regressed on length and dry weight for fish larvae at the experiment's start and finish, respectively (Table 3 ). A power function of

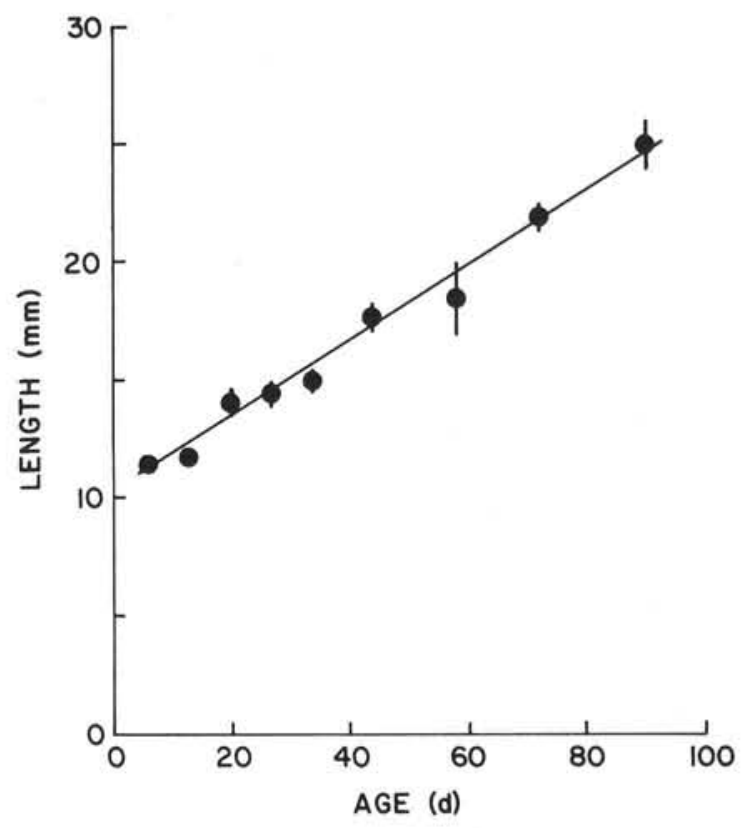

Fig. 1. Relation of standard length to age for herring larvae in the stock population. Mean and $95 \%$ confidence limits of the mean
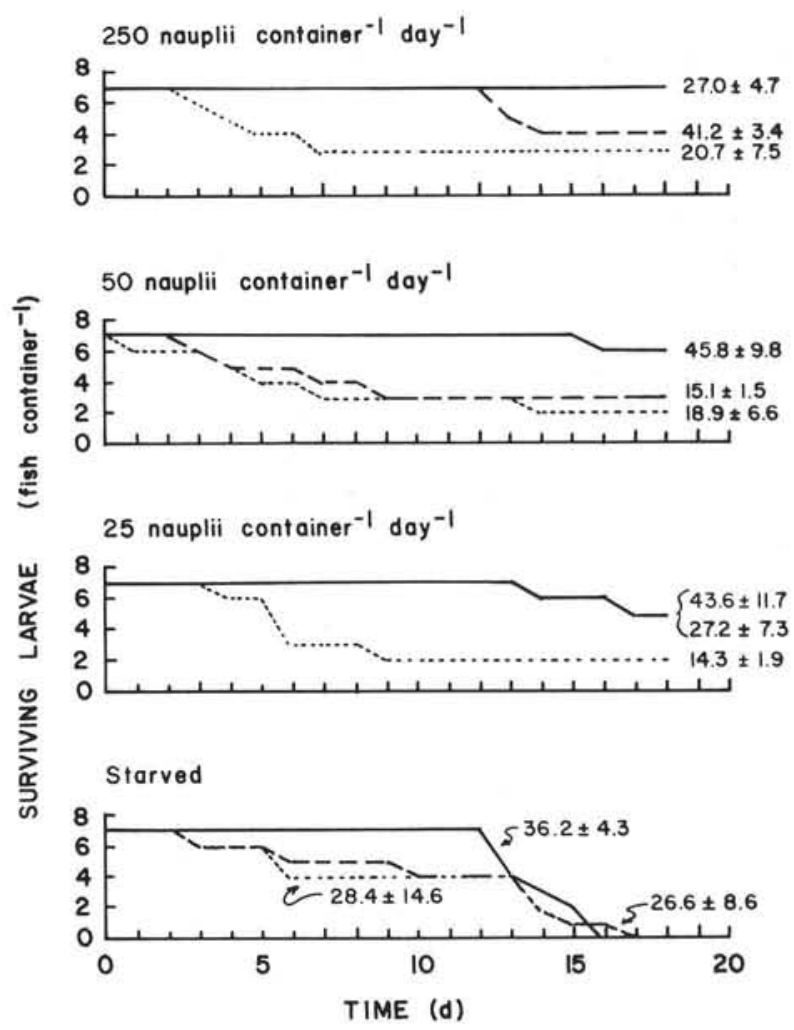

Fig. 2. Survivorship curves for herring larvae in experimental containers. Solid, dashed, and dotted lines correspond to individual containers for each feeding treatment. Mean and $95 \%$ confidence limits of the mean of bodily nitrogen content ( $\mu \mathrm{g} \mathrm{N}$ individual ${ }^{-1}$ ) of fish in each container are shown at right 
Table 3. Regression equations used to estimate nitrogen content $\left(\mathrm{W}_{\mathrm{O}}, \mathrm{W}_{\mathrm{j}} ; \mu \mathrm{gN}\right)$ of fish larvae from (a) length (L, mm) of live, anesthetized fish at the experiment's beginning; (b) dry weight $\left(\mathrm{W}_{\mathrm{D}}, \mu \mathrm{g}\right)$ of fish whose elemental composition was not measured directly upon death or at the experiment's end. The 2 linear regressions have significantly different slopes $\left(\mathrm{F}_{1.28}=11.94\right.$, $\mathrm{p}<0.01$ ); hence their data were not pooled

\begin{tabular}{|llrrrrr}
\hline Category & Regression equation & $\mathrm{r}^{2}$ & $\mathrm{n}$ & & $\mathrm{F}_{1, \mathrm{n}-2}$ & $\mathrm{p}$ \\
\hline Initial & $\mathrm{W}_{\mathrm{O}}=0.0000204 \mathrm{~L}^{5.32}$ & 0.98 & 9 & & 386.6 & $<0.01$ \\
$\begin{array}{l}\text { Final } \\
\text { fed } \\
\text { starved }\end{array}$ & $\mathrm{W}_{\mathrm{j}}=-7.57+0.122 \mathrm{~W}_{\mathrm{D}}$ & 0.95 & 21 & & 359.5 & $<0.01$ \\
& $\mathrm{~W}_{\mathrm{j}}=5.24+0.0638 \mathrm{~W}_{\mathrm{D}}$ & 0.89 & 11 & & 74.26 & $<0.01$ \\
\hline
\end{tabular}

length explained significant variation $\left(\mathrm{r}^{2}=0.98\right.$, $\mathrm{n}=9$ ) in nitrogen content of fish larvae at the experiment's start. This regression was used to estimate the initial nitrogen content from length for each larva in each container, shown at the right in Fig. 2. Linear regressions on dry weight explained significant variation in nitrogen content for both fed $\left(\mathrm{r}^{2}=0.95, \mathrm{n}=21\right)$ and starved $\left(r^{2}=0.89, n=11\right)$ experimental fish larvae. The slopes of these regressions differed significantly $\left(\mathrm{F}_{1,28}=11.94, \mathrm{p}<0.01\right.$; Snedecor and Cochran, 1967) and hence the data were not pooled. These regressions were used to estimate the nitrogen content of fed and starved experimental fish larvae, at the experiment's end, for which dry weight but not elemental composition was measured (52 of 84 individu-
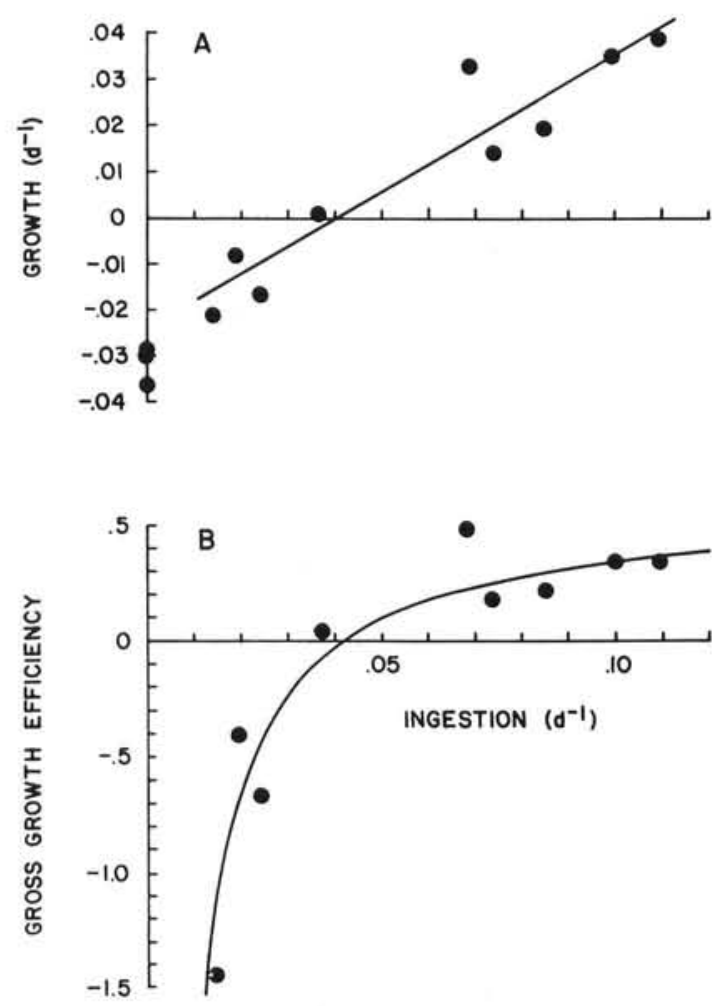

Fig. 3. Growth (A) and gross growth efficiency (B) in relation to ingestion for experimental larvae. Least-squares regressions shown (upper, Eq. 2; lower, Eq. 3) als). One- and $2 \mathrm{~d}$ old Artemia nauplii contained $0.147 \pm 0.005 \mu \mathrm{g} \mathrm{N}$ (mean and $95 \%$ confidence limits of the mean).

Ingestion rate of herring larvae varied between 0.50 and $4.45 \mu \mathrm{g} \mathrm{N}$ larva ${ }^{-1} \mathrm{~d}^{-1}$, equivalent to specific ingestion rates of 0.01 to $0.11 \mathrm{~d}^{-1}$ (i.e. 1 to $11 \%$ of bodily nitrogen $\mathrm{d}^{-1}$; Fig. 3A). Specific growth rate varied from $-0.03 \mathrm{~d}^{-1}$, for starved fish, to $0.04 \mathrm{~d}^{-1}$, for fish with the highest ingestion rate $\left(0.11 \mathrm{~d}^{-1}\right)$, in terms of nitrogen. Growth rate was linearly related to ingestion rate over the range of ingestion rates observed $\left(\mathrm{r}^{2}=\right.$ $0.89, \mathrm{~F}_{1,7}=54.37, \mathrm{p}<0.01$, not including starvation values):

$$
\mathrm{g}=0.59 \mathrm{i}-0.024
$$

Ingestion intercept indicates the ingestion rate which only balances metabolism and defecation and allows no growth, an equivalent of $4 \%$ of bodily nitrogen per day. If the efficiency of nitrogen assimilation is $100 \%$, this intercept is equivalent to the rate of endogenous nitrogen excretion. The rate of weight loss during starvation was approximately 3 to $4 \%$ of bodily nitrogen per day.

Gross growth efficiency rose from below zero, for ingestion rates less than $0.04 \mathrm{~d}^{-1}$, to a maximum of 0.4 at an ingestion rate of $0.11 \mathrm{~d}^{-1}$ (Fig. 3B). A relation between gross growth efficiency and $\mathrm{i}$ was derived by dividing both sides of Eq. 1 by $\mathrm{i}$ :

$$
\mathrm{K}_{1}=0.59-\frac{0.024}{\mathrm{i}}
$$

Ratios of carbon to nitrogen $(\mathrm{C}: \mathrm{N})$, nitrogen to dry weight ( $\mathrm{N}: \mathrm{DW})$, and carbon to dry weight (C:DW) were regressed on ingestion rate (Table 4). Both fed

Table 4. Least-squares regressions of ratios (by mass) of carbon to nitrogen $(C: N)$, nitrogen to dry weight $(N: D W)$, and carbon to dry weight $(C: D W)$ on ingestion rate $\left(i, d^{-1}\right)$

\begin{tabular}{|lllrc|}
\hline Regression equation & \multicolumn{1}{c}{$\mathrm{r}^{2}$} & $\mathrm{n}$ & $\mathrm{F}_{1, \mathrm{n}-2}$ & $\mathrm{p}$ \\
\hline $\mathrm{C}: \mathrm{N}=3.75+0.737 \mathrm{i}$ & 1.0 & 32 & 0.30 & n.s. \\
$\mathrm{N}: \mathrm{DW}=0.0912+0.152 \mathrm{i}$ & 0.18 & 32 & 6.72 & $<0.05$ \\
$\mathrm{C}: \mathrm{DW}=0.340+0.649 \mathrm{i}$ & 0.29 & 32 & 12.48 & $<0.01$ \\
\hline
\end{tabular}


and starved larvae were included in these analyses. $C$ : $N$ had a mean value of $3.78 \pm 0.11$ and was not significantly related to ingestion rate. $\mathrm{N}$ : DW had a mean value of $0.097 \pm 0.005$ and a significant amount, though little, of its variation $\left(\mathrm{r}^{2}=0.18\right)$ was explained by a linear regression on ingestion rate. C : DW had a mean value of $0.364 \pm 0.017$ and was significantly related to ingestion rate $\left(\mathrm{r}^{2}=0.29\right)$. Thus, the amounts of nitrogen and carbon increased relative to dry weight as ingestion increased, although by small amounts. However, the ratio of carbon to nitrogen was independent of ingestion rate and, hence, the relations amongst ingestion and growth presented above in terms of nitrogen are similar in form in terms of carbon. Fish length did not explain significant variation in any of these ratios in either simple or multiple (with i) linear regression analyses.

Condition factor of fed, experimental larvae ranged between 0.0074 and 0.0165 , with a mean value of $0.0112 \pm 0.0011$. A stepwise, multiple linear regression was performed to investigate the possible relationship of fish length $(\mathrm{L}, \mathrm{mm})$ and ingestion rate $\left(\mathrm{i}, \mathrm{d}^{-1}\right)$ to variations in the condition factor. The regression is significant $\left(\mathrm{F}_{2,17}=18.84, \mathrm{p}<0.01\right)$ and accounts for $69 \%$ of the variation in condition factor:

$$
\mathrm{CF}=-0.0056+0.0010 \mathrm{~L}+0.0378 \mathrm{i}
$$

Each independent variable accounts for a significant reduction in the error mean square when entered last in the regression (length: $F_{1,17}=11.28, p<0.01$; ingestion: $F_{1,17}=18.33, p<0.01$ ). Hence, longer and well-fed larvae were more truncate than shorter and malnourished larvae of the same age. The condition factor of starved larvae could not be measured.

\section{DISCUSSION}

Atlantic herring larvae. Growth rate of herring larvae in the stock population, $.17 \mathrm{~mm} \mathrm{~d}^{-1}$, is similar to growth rate estimates for other populations of reared herring larvae but lower than estimates for larvae in large enclosures and the sea. Growth rates reported for post-yolk sac larvae of Clupea harengus maintained in the laboratory are $0.22 \mathrm{~mm} \mathrm{~d}^{-1}$ (spring spawned, 0 to $91 \mathrm{~d}$ old; Ehrlich et al., 1976) and $0.12 \mathrm{~mm} \mathrm{~d}^{-1}$ (spring spawned; 4 to $12 \mathrm{wk}$ old; Werner and Blaxter, 1980). Rates up to $0.24 \mathrm{~mm} \mathrm{~d}^{-1}$ were observed for larvae ( 0 to 5 wk old) of Pacific herring (C. harengus pallasi, spring spawning) reared by Haegle and Outram (1978). Reported rates of growth of larvae in wild populations range from $0.17 \mathrm{~mm} \mathrm{~d}^{-1}$ (autumn spawned, $<10 \mathrm{~mm}$; Schnack, 1972) to $0.46 \mathrm{~mm} \mathrm{~d}^{-1}$ (spring spawned, hatching to metamorphosis; Marshall et al., 1937). A single experiment in a broad, shallow basin in Norway yielded a growth rate of $0.44 \mathrm{~mm} \mathrm{~d}^{-1}$ (spring spawned, 8 to $44 \mathrm{~d}$ old; Oiestad and Moksness, 1981). The temperature of the present experiment $\left(7\right.$ to $\left.9^{\circ} \mathrm{C}\right)$ was slightly lower than the mean temperature in other rearing experiments and nature but not enough to account for the observed variations in growth rate.

The exponential coefficient relating dry weight to length for larvae in the stock culture (4.73) is slightly higher than other reported values. Exponential coefficients include 3.8 and 4.2 (Gamble et al., 1981), 4.30 (Laurence, 1978), 4.53 (Marshall et al., 1937), 4.49 (Sameoto, 1972), and 4.57 (Ehrlich et al., 1976). The slightly higher value in the present study may be due to an improvement of condition of the average larva with age, the result of differential mortality of slowgrowing larvae in the stock population.

The death of experimental herring larvae is attributed primarily to either poor initial condition, for those dying between 2 and $9 \mathrm{~d}$, or starvation, for those dying between 12 and $17 \mathrm{~d}$. Mortality appeared unrelated to ingestion rate for fed larvae during this $18 \mathrm{~d}$ experiment: larvae fed the lowest rations lost weight but did not die. The mean bodily nitrogen content of starved fish at death was $20.6 \pm 2.8 \mu \mathrm{g} \mathrm{N}$. The mean bodily nitrogen of fish fed the lowest ration was $28.9 \pm$ $5.6 \mu \mathrm{g} \mathrm{N}$ at the experiment's end. By contrast, the best fed larvae contained $54.7 \pm 11.6 \mu \mathrm{g} \mathrm{N}$. Hence, it appears that surviving, poorly-fed fish still had metabolizable reserves but that starvation death was imminent.

Ratios of nitrogen and carbon to dry weight (N : DW, C : DW) increased as rate of ingestion increased, although the ratio of carbon to nitrogen $(C: N)$ was unrelated to ingestion rate. These results may be compared to those of Ehrlich $(1974 a, b)$ for starved and sated herring and plaice larvae. Ehrlich observed decreases in $\mathrm{N}$ : DW and $\mathrm{C}$ : DW during starvation, although the observed changes were of greater magnitude than in the present study. Ehrlich also observed a decrease in $\mathrm{C}: \mathrm{N}$ during starvation, indicating the loss of carbohydrate and/or lipid relative to protein during starvation. $\mathrm{C}: \mathrm{N}$ was unrelated to ingestion in the present study. Whereas Ehrlich investigated the extremes of nutrition, starvation and satiation, the present study concerned a range of ingestion rates. No doubt, with time, larvae acquiring food at a rate below maintenance would also change significantly in composition and become similar to starved fish. Thus, the ratios $\mathrm{N}: \mathrm{DW}, \mathrm{C}: \mathrm{DW}$, and $\mathrm{C}: \mathrm{N}$ appear more useful for identifying the exceptional case of terminallystarved rather than poo -fed fish larvae. Ehrlich (1974a) also showed these ratios are related to the length and, less so, the age of sated larvae. Hence, chemical composition alone, in terms of the relative amounts of dry matter, carbon, and nitrogen, is 
unlikely to provide a useful index of the nutrition of sea-caught fish larvae, due to its relatively small variation with ingestion rate and its confounding variation with the age and length of larvae. Finally, it is doubtful whether malnourished fish larvae survive long enough in the sea to show significant variation in their composition.

Previous laboratory studies (Blaxter, 1971) and the present study show the condition factor of growing larvae to increase with increasing length. This is expected, given the relation of weight to length to be a power function with an exponential coefficient exceeding 3 . The multiple regression (Eq. 4) indicates that if variation of either length or ingestion rate can be controlled, significant variation in the condition factor can be explained by the remaining independent variable. Thus, for fish of similar age and length, the condition factor may provide a useful index of nutrition. Its optimal use, however, requires the development of relationships between the condition factor, length, and ingestion rate under controlled, laboratory conditions, as well as the ability to compare wild fish of similar age and length. Age estimation of larvae by otolith analysis (Methot and Kramer, 1979) should facilitate this use of the condition factor. The condition factor is known to decline during starvation for herring larvae (Blaxter, 1971; Ehrlich, 1974a) and the values reported here are consistent with most published values. Thus, the condition of Atlantic herring reared in the laboratory was 0.014 to 0.016 for fed larvae and 0.009 to 0.010 for $10 \mathrm{~d}$ starved larvae at $38 \mathrm{~d}$ after hatching (Ehrlich et al., 1976). Blaxter (1971) obtained higher values for starved larvae of Atlantic herring ( 0.012 to 0.014$)$, although these may be artifacts, due to the use of formalin-preserved specimens in which shrinkage is known to occur (Hay, 1981). A similar relation between the condition factor and ingestion rate was observed for juvenile cod Gadus morhua (Edwards et al., 1972). Hence, these laboratory results also indicate that for fish of a limited size range the condition factor varies directly with ingestion. In particular, the present results and those of Ehrlich et al. (1976) indicate that herring larvae of 14 to $17 \mathrm{~mm}$ would have a condition factor of less than 0.010 if starved and greater than 0.013 if well-nourished. Values for wild-caught larvae of this size indicate good nutrition in most cases. Clyde herring sampled by Marshall et al. (1937) had values of 0.013 to 0.016 . Values for Pacific herring range between 0.013 and 0.017 (Westernhagen and Rosenthal, 1981). These data are consistent with the hypothesis that herring larvae surviving in the sea are well-nourished but are insufficient to refute the hypothesis that some larvae in the sea are malnourished.

Growth of the experimental fish larvae was a linear function of ingestion. The maintenance ingestion rate $\left(0.04 \mathrm{~d}^{-1}, \mathrm{x}\right.$-intercept; Fig. $\left.3 \mathrm{~A}\right)$ is the rate of ingestion necessary to just balance metabolic and fecal losses and compares favorably with the specific respiration rate of non-feeding larvae in other studies, considering fecal losses and differences in experimental conditions. In converting a respiration rate $\left(Q_{\mathrm{O}_{2}}, \mu \mathrm{l} \mathrm{O}_{2} \mathrm{mg}\right.$ dry $\mathrm{wt}^{-1} \mathrm{~h}^{-1}$ ) to a specific metabolic rate in terms of dry weight $\left(\mathrm{d}^{-1}\right)$, values of $4.9 \mathrm{cal} \mathrm{ml} \mathrm{O}_{2}^{-1}$ and $5.6 \mathrm{cal}$ mg dry $\mathrm{wt}^{-1}$ are assumed (Winberg, 1971). Holliday et al. (1964) obtained values of 0.046 to $0.053 \mathrm{~d}^{-1}$ for anesthetized larvae of Atlantic herring from near Kiel and Bergen, respectively, at $8^{\circ} \mathrm{C}$. DeSilva and Tytler (1973) obtained values of $0.025 \mathrm{~d}^{-1}$ (anesthetized) to $0.050 \mathrm{~d}^{-1}$ (unanesthetized) for $2 \mathrm{wk}$ old larvae of Atlantic herring at $10^{\circ} \mathrm{C}$. Similarly, starved larvae in the present study lost weight at a rate of 0.028 to $0.036 \mathrm{~d}^{-1}$, comparable to Ehrlich's (1974a) estimate of the weight loss during starvation at 8 to $12^{\circ} \mathrm{C}$, estimated to be $0.05 \mathrm{~d}^{-1}$. Hence, despite differences in experimental conditions (e.g. temperature and activity), the present and previously-reported results compare favorably and indicate that herring larvae ingest the equivalent of approximately $4 \%$ of their bodily mass per day for maintenance and, when starved, metabolize three percent of their bodily mass per day.

The highest specific growth rate observed here, $0.04 \mathrm{~d}^{-1}$, is similar to other values for reared herring larvae but significantly less than values reported for enclosure studies and those estimated for wild herring. Werner and Blaxter (1980) obtained growth rates of 0.018 to $0.036 \mathrm{~d}^{-1}$ for larval Atlantic herring fed Artemia at $9^{\circ} \mathrm{C}$. By contrast, the data of Marshall et al. (1937) provide a growth estimate for wild larvae in the Firth of Clyde of approximately $0.14 \mathrm{~d}^{-1}$. Oiestad and Moksness (1981) estimated the growth of Atlantic herring larvae in a large, artificial pond to be $0.12 \mathrm{~d}^{-1}$, while Gamble et al. (1981) measured a rate of $0.077 \mathrm{~d}^{-1}$ for larvae in a large plastic enclosure. The discrepancy between the growth rates of herring larvae in laboratory studies, the present work included, and those for larvae in the sea and large enclosures may be due to the selective mortality of slower growing individuals and/or the faster growth of the average larva in large enclosures and the sea, due to different environmental conditions, especially food and predators. Although the selective mortality of malnourished larvae is no doubt significant (cf. Bailey and Yen, 1983), the results of Oiestad and Moksness (1981) indicate that fast growth of the average larva is also possible: in that study, growth, in terms of both length and weight, was rapid and survival high ( $70 \%$ ) over a $130 \mathrm{~d}$ period in a large basin free of most predators.

A linear relation between the rates of growth and ingestion (Fig. 3A) indicates that constant fractions of 
food ingested in excess of the maintenance ingestion rate are allocated to growth and metabolism plus feces. If the assimilation efficiency is constant over this range of ingestion rates, this indicates that the rate of metabolism increases in proportion to the rate of ingestion. In the present study, constant fractions of nitrogen in food ingested in excess of maintenance $\left(0.03 \mathrm{~d}^{-1}\right)$ were allocated to growth (0.59) and metabolism plus feces $(0.41)$. This form of relation compares well with that found in similar studies of nitrogen with juvenile and adult fish, although the slope $(0.59)$ is higher. Birkett (1969) obtained slopes ranging between 0.25 and 0.44 for a variety of species of marine fish and estimated values between 0.26 and 0.67 for other studies reported in the literature. Gerking (1971), in a study similar to the present one, but using bluegill sunfish of a range of sizes, obtained slopes ranging from .44 (smallest fish) to .14 (largest fish). Durbin and Durbin (1981) obtained a value of .32 for adult Atlantic menhaden. Hence, these results indicate that herring larvae, like juveniles and adults of other fish species, transform a constant fraction of nitrogen ingested in excess of maintenance into tissue, but with a greater efficiency.

The gross growth efficiency of herring larvae in the present study attained a maximal value of approximately 0.4 (Fig. 3B). A linear extrapolation of the relation between rates of growth and ingestion (Eq. 2) yields an asymptote for the gross growth efficiency of 0.59 (Eq. 3). However, a linear extrapolation to such high growth rates is unrealistic and the gross growth efficiency more likely has a maximal value of 0.4 to 0.5 . The maximum reported growth rate for larval herring, $0.14 \mathrm{~d}^{-1}$ (Marshall et al., 1937), corresponds to an ingestion rate of $0.28 \mathrm{~d}^{-1}$ (Eq. 2) and gross growth efficiency of 0.50 (Eq. 3).

General relations. The data reported here for larvae of Atlantic herring are consistent with those for larvae of other species and, together, provide a general relation of growth to ingestion for larval fish. Below, I analyze studies (Table 5) in which rates of ingestion and growth were measured directly, by difference (i.e. food depletion and weight gain, respectively), and which provide for or allow the computation of weightspecific rates in units of $\mathrm{d}^{-1}$. All rates have been normalized to $8{ }^{\circ} \mathrm{C}$, for comparison with data of the present study, by assuming a $Q_{10}$ of 2.3 (Brett and Groves, 1979) for growth and ingestion. I do not imply that individual species of fish are each able to function at $8^{\circ} \mathrm{C}$. However, implicit in this assumption is that the gross growth efficiency is independent of temperature (Targett, 1979); i.e. that rates of growth and ingestion have similar variations with temperature. The relation of growth to ingestion for the combined data is shown in Fig. 4. A logarithmic function of ingestion accounts for significant variation in growth $\left(\mathrm{r}^{2}=0.85, \mathrm{~F}_{1,18}=\right.$ $101.0, \mathrm{p} \ll 0.01$ ):

$$
\mathrm{g}=0.13+0.088 \log _{10} \mathrm{i}
$$

This is a surprisingly good fit considering the diverse taxa and experimental conditions from which the data

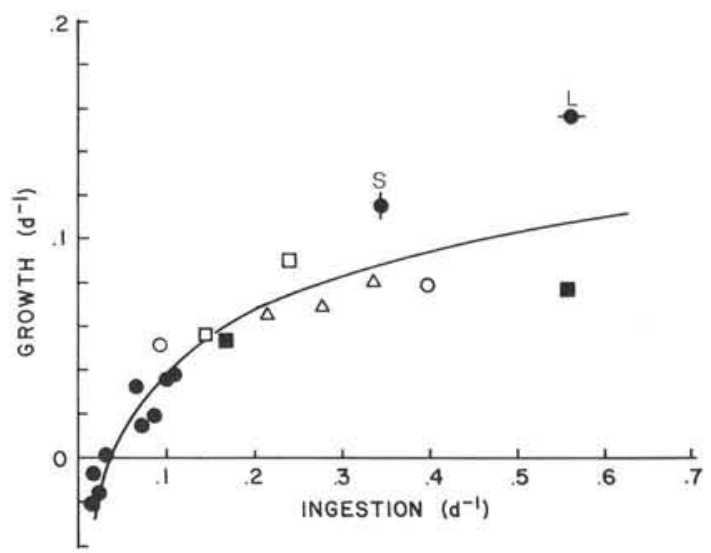

Fig. 4. Growth in relation to ingestion for larvae of herring and other species, normalized to $8^{\circ} \mathrm{C}$ (see text and Table 5 for details). (•) Clupea harengus: present study; (घ) Anchoa mitchelli: Houde and Schekter (1981); (O) Achirus lineatus: ditto; ( $\square$ ) Archosargus rhomboidalis: ditto; $(\Delta)$ Archosargus rhomboidalis: Stepien (1976); (S) Scober japonicus: Hunter and Kimbrell (1980); (L) Leuristhes tenuis: May (1971). Leastsquares regression is Eq. 5

Table 5. Studies of larval fish in which ingestion, feeding, and fish weights were measured directly, enabling computation of specific rates and gross growth efficiency. All rates measured in terms of dry weight except in the present study, in which nitrogen is the basis

\begin{tabular}{|lccll|}
\hline \multicolumn{1}{|c}{ Species } & $\begin{array}{c}\text { Age } \\
(\mathrm{d})\end{array}$ & $\begin{array}{c}\text { Temperature } \\
\left({ }^{\circ} \mathrm{C}\right)\end{array}$ & \multicolumn{1}{c|}{ Food } & Reference \\
\hline Anchoa mitchelli & $2-21$ & 26 & wild plankton & Houde and Schekter (1981) \\
Archirus lineatus & $2-17$ & 26 & wild plankton & ibid. \\
Archosargus rhomboidalis & $2-15$ & 26 & wild plankton & Stepien (1976) \\
Archosargus rhomboidalis & $2-16$ & $23-26$ & wild plankton & Hunter and Kimbrell (1980) \\
Scomber japonicus & $3-6$ & 19 & Brachionus pileatus & May (1971) \\
Leuristhes tenuis & $7-22$ & 18 & Artemia salina & Present study \\
Clupea harengus & $20-38$ & $7-8$ & Artemia salina & \\
\hline
\end{tabular}


were derived. This logarithmic relation, obtained for these general data, is consistent with the linear relation (Eq. 2) obtained for herring larvae in the present study, in which variations in growth rate were equally well explained by linear $\left(\mathrm{r}^{2}=0.89, \mathrm{n}=9\right)$ and logarithmic $\left(r^{2}=0.88, n=9\right)$ functions over the limited range of ingestion rates encountered. It is apparent, however, that the linear function should not be extrapolated beyond the range of experimentallyobserved ingestion rates. The corallary relation between gross growth efficiency and ingestion, derived from Eq. 5, and shown in Fig. 5, is:

$$
\mathrm{k}_{1}=\left(0.13+0.088 \log _{10} \mathrm{i}\right) / \mathrm{i}
$$

It is apparent that the relations of growth rate (normalized to $8^{\circ} \mathrm{C}$ ) and gross growth efficiency (unaltered) to ingestion rate are consistent with those reported here for larvae of Atlantic herring. Thus, maximal growth at $8^{\circ} \mathrm{C}$ is estimated to be approximately $0.11 \mathrm{~d}^{-1}$ (observed range, 0.07 to 0.15 ), near to that observed by Marshall et al. (1937) for wild larvae of herring in the Clyde $\left(0.14 \mathrm{~d}^{-1}\right)$. Maximal gross growth efficiency, approximately 0.4 , occurs at an ingestion rate of $0.1 \mathrm{~d}^{-1}$ at $8^{\circ} \mathrm{C}$.

It is useful to compare these general relations for larval fish with those for fish at other stages of development. Growth rate is usually observed to be a monotonically-increasing function of ingestion rate and, in most cases, either the initial or entire portion of the relation can be approximated by a linear function (e.g.

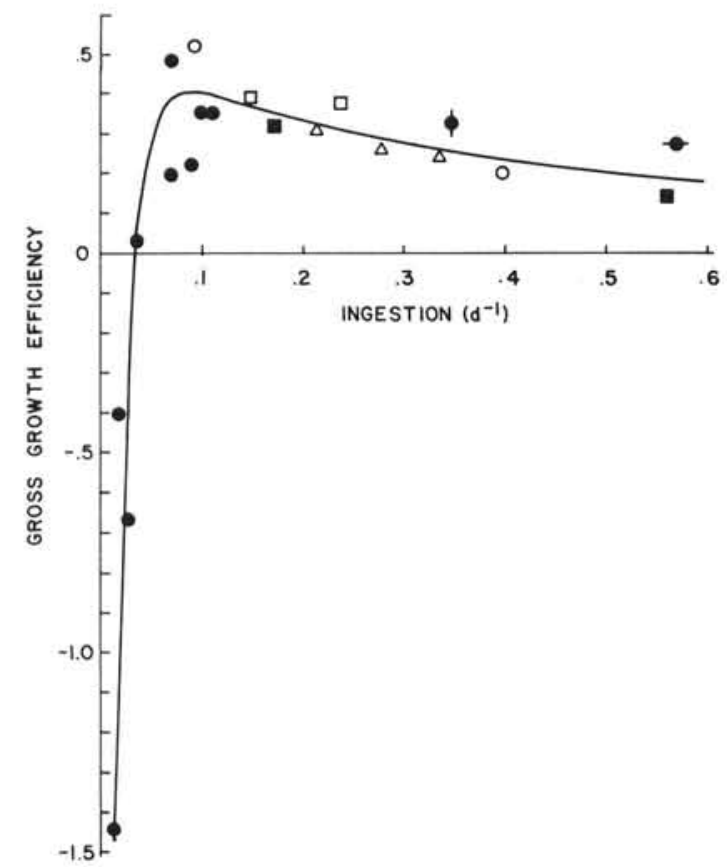

Fig. 5. Gross growth efficiency in relation to specific ingestion for larvae of herring and other fish, normalized to $8^{\circ} \mathrm{C}$. Symbols as in Fig. 4. Curve is Eq. 6
Gerking, 1971; Jones, 1976; Kausch and Zimmerman, 1976; Savitz et al., 1977), as in the present study. At high rates of ingestion, however, growth becomes physiologically-limited while ingestion may continue to increase (cf. Webb, 1978; Brett and Groves, 1979; Condrey, 1982, and references therein). Hence, gross growth efficiency attains a maximal value at an intermediate ingestion rate, estimated here for larval fish to be approximately $0.4\left(\mathrm{~K}_{1}\right)$ at $0.1 \mathrm{~d}^{-1}$ (i) for $8^{\circ} \mathrm{C}$. This maximal gross growth efficiency for fish larvae is intermediate in value to the efficiency of yolk utilization by fish embryos and larvae and the gross growth efficiency of juvenile and adult fish. Lasker (1962) obtained values of 0.77 to 0.79 for the conversion of yolk to tissue by the Pacific sardine. Blaxter and Hempel (1966) obtained values for Atlantic herring larvae of 0.49 to 0.74 and cited literature values of 0.42 to 0.60 for several salmonid species. Eldridge et al. (1977) reported a yolk utilization efficiency of 0.74 for embryos and of 0.44 for larvae of Pacific herring. Similarly, the efficiency of converting yolk for embryos of other organisms is approximately 0.6 (Calow, 1977). Gross growth efficiency of metazoa (Calow, 1977), including fish (Brett and Groves, 1979), decreases with size, in association with a decrease in specific growth rate and a relative increase in specific metabolic rate. Gross growth efficiency of juvenile fish is usually less than 0.35 (Brett and Groves, 1979). Finally, the peaked form of the relation between growth efficiency and ingestion rate (Fig. 5) explains the inverse relation between these 2 variables observed in previous studies of larval fish (e.g. Stepien, 1976; Houde and Schekter, 1981).

Growth rate continues to increase at high rates of ingestion despite a decline in gross growth efficiency. The increasing portion of the ingested food not used for growth must be either defecated or metabolized. A recent study of larval Pacific herring shows that growth rate continues to increase but assimilation efficiency declines at high ingestion rates (Boehlert and Yoklavich, in press), indicating an increase in the defecated rather than metabolized fraction. Hence, fish larvae may maximize either their rate of growth or gross growth efficiency, but not both simultaneously.

These general relations may be used, with the $Q_{10}$ of 2.3 , to derive an equation to estimate the ingestion rate $\left(i, d^{-1}\right)$ of a larval fish of known growth rate $\left(g, d^{-1}\right)$ and temperature $\left(\mathrm{t},{ }^{\circ} \mathrm{C}\right)$ :

$$
i=2.3^{[(t-8) / 10]} 10^{\left[g / 2.3^{(t-8) / 10]}-0.129\right] / 0.0875}
$$

Ingestion rates predicted by this equation may be used with a suitable feeding model (e.g. a functional response; Holling, 1959) to predict the concentration of prey necessary to sustain growth at a particular rate and temperature. 


\section{CONCLUSIONS}

The general relations derived here provide insight into the growth dynamics of larval fish in nature. Reported studies of wild larvae only rarely indicate malnutrition of a significant portion of a sampled population. Condition factors estimated for larval herring are, in most cases, high (Vilela and Zijlstra, 1971; Schnack, 1972; Westernhagen and Rosenthal, 1981). Growth rates estimated by following a cohort (herring larvae: Marshall et al., 1937) and otolith analyses (southern anchovy larvae: Methot and Kramer, 1981) indicate rapid growth for a particular temperature. Morphological and histological studies also indicate good nutrition (O'Connell, 1980). Finally, Buckley's $(1979,1980)$ studies of the ratio of RNA to DNA reveal good nutrition and rapid growth of sea-caught larvae of cod and winter flounder. These results all indicate that larvae collected at sea are well-nourished and growing rapidly. The present results suggest that fish, whose larvae surviving in the sea grow rapidly, have evolved so that the rate of growth rather than the growth efficiency of their larvae is maximal.

Acknowledgements. This research was made possible by a NATO Postdoctoral Fellowship in Science awarded to D. Checkley. Support of the Marine Laboratory of the Department of Agriculture and Fisheries for Scotland, especially Drs. J. Gamble and I. Baxter, is gratefully appreciated. The salmon fishers of Aberdeen also provided invaluable assistance. Dr. S. D. Gerking, 2 anonymous reviewers, and Drs. J. Cullen, J. Steele, and D. Wohlschlag offered constructive comments.

\section{LITERATURE CITED}

Bailey, K. M., Yen, J. (1983). Predation by a carnivorous marine copepod, Euchaeta elongata Esterly, on eggs and larvae of the Pacific hake. J. Plankton Res. 5: 71-82

Birkett, L. (1969). The nitrogen balance in plaice, sole and perch. J. exp. Biol. 50: 275-306

Blaxter, J. H. S. (1968). Rearing herring larvae to metamorphosis and beyond. J. mar. biol. Ass. U.K. 48: 17-28

Blaxter, J. H. S. (1971). Feeding and condition of Clyde herring larvae. Rapp. P.-v. Reun. Cons. int. Explor. Mer 160: 128-136

Blaxter, J. H. S., Hempel, G. (1966). Utilization of yolk by herring larvae. J. mar. biol. Ass. U.K. 46: 219-234

Boehlert, G. W., Yoklavich, M. M. (in press). Carbon assimilation as a function of ingestion rate in larval Pacific herring, Clupea harengus pallasi Valenciennes. J. exp. mar. Biol. Ecol.

Brett, J. R., Groves, T. D. D. (1979). Physiological energetics. In: Hoar, W. J., Randall, D. J., Brett, J. R. (ed.) Fish physiology, Vol. VIII. Academic Press, New York, p. $279-352$

Buckley, L. J. (1979). Relationships between RNA-DNA ratio, prey density and growth rate in Atlantic cod (Gadus morhua) larvae. J. Fish. Res. Bd Can. 36: 1497-1502

Buckley, L. J. (1980). Changes in ribonucleic acid, deoxy- ribonucleic acid, and protein content during ontogenesis in winter flounder, Pseudopleuronectes americanus, and effect of starvation. Fish. Bull. U.S. 77: 703-708

Calow, P. (1977). Conversion efficiencies in heterotrophic organisms. Biol. Rev. 52: 385-409

Checkley, D. M., Jr. (1980). The egg production of a marine, planktonic copepod in relation to its food supply: laboratory studies. Limnol. Oceanogr. 25: 430-446

Condrey, R. E. (1982). Ingestion-limited growth of aquatic animals: the case for Blackman kinetics. Can. J. Fish. aquat. Sci. 39: 1585-1595

DeSilva, C. D., Tytler, P. (1973). The influence of reduced environmental oxygen on the metabolism and survival of herring and plaice larvae. In: deBlok, J. W. (ed.) Proceedings of the 7 th European marine biology symposium. Neth. J. Sea Res. 7: 345-362

Durbin, E. G., Durbin, A. G. (1981). Assimilation efficiency and nitrogen excretion of a filter-feeding planktivore, the Atlantic menhaden, Brevoortia tyrannus. Fish. Bull. U.S. 79: 601-616

Edwards, R. R. C., Finlayson, D. M., Steele, J. H. (1969). The ecology of 0-group plaice and common dabs in Loch Ewe, II. Experimental studies of metabolism. J. exp. mar. Biol. Ecol. 32: 1-17

Edwards, R. R. C., Finlayson, D. M., Steele, J. H. (1972). An experimental study of the oxygen consumption, growth and metabolism of the cod (Gadus morhua L.). J. exp. mar. Biol. Ecol. 81: 299-309

Ehrlich, K. F. (1974a). Chemical changes during growth and starvation of herring larvae. In: Blaxter, J. H. S. (ed.) The early life history of fish. Springer-Verlag, New York, p. 301-323

Ehrlich, K. F. (1974b). Chemical changes during growth and starvation of larval Pleuronectes platessa. Mar. Biol. 24: $39-48$

Ehrlich, K. F., Blaxter, J. H. S., Pemberton, R. (1976). Morphological and histological changes during the growth and starvation of herring and plaice larvae. Mar. Biol. 35: 105-118

Eldridge, M., Echeverria, T., Whipple, J. A. (1977). Energetics of Pacific herring (Clupea harengus pallasi) embryos and larvae exposed to low concentrations of benzene, a monoaromatic component of crude oil. Trans. Am. Fish. Soc. 106: 452-461

Gamble, J. C., MacLachlan, P., Nicol, N. T., Baxter, I. G. (1981). Growth and feeding of Atlantic herring larvae reared in large plastic enclosures. Rapp. P.-v. Réun. Cons. int. Explor. Mer 178: 121-134

Gerking, S. D. (1971). Influence of rate of feeding and body weight on protein metabolism of bluegill sunfish. Physiol. Zool. 44: 9-19

Haegle, C. W., Outram, D. N. (1978). The effects of diet and ration on the growth and survival of Pacific herring (Clupea harengus pallasi) larvae. Can. Fish. Mar. Serv. Tech. Rept. 767: 1-41

Hay, D. E. (1981). Effects of capture and fixation on gut contents and body size of Pacific herring larvae. Rapp. P.v. Réun. Cons. int. Explor. Mer 178: 395-400

Hempel, G., Blaxter, J. H. S. (1963). On the condition of herring larvae. Rapp. P.-v. Réun. Cons. int. Explor. Mer 154: $35-40$

Holliday, F. G. T., Blaxter, J. H. S., Lasker, R. (1964). Oxygen uptake of developing eggs and larvae of the herring (Clupea harengus). J. mar. biol. Ass. U.K. 44: 711-723

Holling, C. S. (1959). The components of predation as revealed by a study of small-mammal predation of the European Pine Sawfly. Can. Ent. 91: 293-320 
Houde, E. D., Schekter, R. C. (1981). Growth rates, rations and cohort consumption of marine fish larvae in relation to prey concentrations. Rapp. P.-v. Réun. Cons. int. Explor. Mer 178: 441-453

Hunter, J. R., Kimbrell, C. A. (1980). Early life history of pacific mackerel, Scomber japonicus. Fish. Bull. U.S. 78: 89-101

Ivlev, V. S. (1961). Experimental ecology of the feeding of fishes. Yale Univ. Press, Inc.

Jones, R. (1976). Growth of fishes. In: Cushing, D. H., Walsh, J. J. (ed.) The ecology of the seas. Saunders, Philadelphia, p. 251-279

Kausch, H., Zimmerman, C. (1976). Gross growth efficiency and growth of young whitefish Coregonus fera fed on pond zooplankton. Arch. Hydrobiol. 48 (Suppl. B): 181-206

Lasker, R. (1962). Efficiency and rate of yolk utilization by developing embryos and larvae of the Pacific sardine, Sardinops caerulea (Girard). J. Fish. Res. Bd Can. 19; 867-875

Laurence, G. C. (1978). Larval length-weight relations for seven species of northwest Atlantic fishes reared in the laboratory. Fish. Bull. U.S. 76: 890-895

Marshall, S. H., Nicholls, A. G., Orr, A. P. (1937). On the growth and feeding of the larval and post-larval stages of the Clyde herring. J. mar. biol. Ass. U.K. 22: 245-267

May, R. C. (1971). Effects of delayed initial feeding on larvae of the grunion, Leuresthes tenuis (Ayres). Fish. Bull. U.S. 69: $411-425$

Methot, R. D., Kramer, D. (1979). Growth of northern anchovy, Engraulis mordax, larvae in the sea. Fish. Bull. U.S. 77: 413-423

Morgan, P. H. (1981). Utilization of growth constants as response variables in experimental nutrition. Nutr. Abstr. Rev. 39: 321-327

O'Connell, C. P. (1980). Percentage of starving northern anchovy, Engraulis mordax, larvae in the sea as estimated by histological methods. Fish. Bull. U.S. 78: 475-489

Oiestad, V., Moksness, E. (1981). Study of growth and survival of herring larvae (Clupea harengus L.) using plastic bag and concrete basin enclosures. Rapp. P.-v. Réun. Cons. int. Explor. Mer 178: 144-149

Roughgarden, J. (1971). Density dependent natural selection. Ecology 52: 453-468
Sameoto, D. D. (1972). Distribution of herring (Clupea harengus) larvae along the southern coast of Nova Scotia with observations on their growth and condition factor. J. Fish. Res. Bd Can. 29: 507-515

Savitz, J., Albenese, E., Evinger, M. J., Kolansinski, P. (1977). Effect of ration level on nitrogen excretion, nitrogen retention and efficiency of nitrogen utilization for growth in largemouth bass (Micropterus salmoides). J. Fish. Biol. 11: 185-192

Schnack, D. (1972). Studies on the food ecology of herring larvae. Ber. dt. wiss. Kommn Meeresforsch. 22: 273-343

Snedecor, G. W., Cochran, W. G. (1967). Statistical methods, 6 th ed. Iowa St. Univ., Ames

Stepien, W. P., Jr. (1976). Feeding of laboratory-reared larvae of the sea bream Archosargus rhomboidalis (Sparidae). Mar. Biol. 38: 1-16

Targett, T. E. (1979). The effect of temperature and body size on digestive efficiency in Fundulus heteroclitus (L.). J. exp. mar. Biol. Ecol. 38: 179-186

Theilacker, G. H. (1978). Effect of starvation on the histological and morphological characteristics of jack mackerel, Trachurus symmetricus, larvae. Fish. Bull. U.S. 76: 403-414

Thomas, W. H. (1970). Effect of ammonium and nitrate concentration on chlorophyll increases in natural tropical Pacific phytoplankton populations. Limnol. Oceanogr. 15: 386-394

Vilela, M. H., Zijlstra, J. J. (1971). On the condition of herring larvae in the central and southern North Sea. Rapp. P.-v. Reun. Cons. int. Explor. Mer 160: 137-141

Webb, P. W. (1978). Partioning of energy into metabolism and growth. In: Gerking, S. D. (ed.) Ecology of freshwater fish production. Wiley, New York, p. 184-214

Werner, R. G., Blaxter, J. H. S. (1980). Growth and survival of larval herring (Clupea harengus) in relation to prey density. Can. J. Fish. aquat. Sci. 37: 1063-1069

Westernhagen, H. V., Rosenthal, H. (1981). On condition factor measurements in Pacific herring larvae. Helgoländer Meeresunters. 34: 257-262

Winberg, G. C. (ed.) (1971). Methods for the estimation of production of aquatic animals. Academic Press, New York 